secondly, with automata theory for the description of other phonomena as languages; artificial languages in information rotrioval systoms, including a briof consideration of the algorithmic language ALGOL; inference in information retrieval systoms; and theoretical foasibility and complexity questions. The bibliography consists of 321 items.

\section{Research in Space Science}

Selfeted papors from the Special Roports in Space Science issued by the Astrophysical Observatory of the Smithsonian Institution during the years 1958-61 are brought together in Smithsonian Contributions to Astrophysics, 6, Research in Space Science (Pp. vii +242. Washington, D.C.: Government Printing Office, 1963. 2 dollars). The Smithsonian Astrophysical Obsorvatory has been among tho leaders in sevoral branches of space research-the optical tracking of satollites, the determination of orbits from observation, the use of these orbits for geophysical studies, the dovolopment of orbital thoory, otc. - and the papers are, therefore, of considerablo interest as a record of progress in these subjects. Some of them aro printed as they originally appoarod (including one which was in error and is correctod 15 pages later); but others have been revised in varying degrees. The authors include regular mermbers of the Smithsonian Astrophysical Observatory, such as I. G. Jacchia and T. G. Izsak, and visiting consultants, such as M. Nicolet and Sir Harold Jeffreys. This publication is supplemented by Smithsonian Contributions to Astrophysics, 8, No. 1, Accurate Drag Determinations for Eight Artificial Satel. lites, Atmospheric Densities and Temperatures, by L. (G. Jacchia and J. Slowey (Pp. ii +99 . Washington, D.C.: (Yovernment Printing Office, 1963. 65 cents). In this report the rato of decrease of orbital poriod for eight satellites during the years 1958-61 is ovaluated from field-reduced obsorvations with Baker--Nunn camoras, and tho upper-atmosphere densities and temperatures aro then determined. The report is notable for its accuracy and wealth of dotail, the variations in density and tomporatures at hoights of $300-700 \mathrm{~km}$, both short-term and year-by-year, being fully displayed.

\section{Chesapeake Bay Bridge-Tunnel}

Sowe facts about the noarly completed bridge and tunnel erossing from Wiso Point, Va., to the Virginia shore 15 miles from downtown Norfolk are of interest to Britain and France in view of the controversy that has raged over the possibility of bridging the English Channol, as opposed to a tunnel link under the Straits of Dover. This project overcomes the last and most formidable obstacle on the 998-milo Ocoan Highway between New York and Florida. It is acclaimed not only as one of the world's modern engineering wonders but also as ". . . man's longest span across navigablo ocean water". "The stream of seagoing traffic will inaugurate a spectacular 17.6-mile systom of trestles, man-mado islands and tunnels that draws the boundary between the Atlantic Ocean and Chesapeake Bay". More than two-thirds of this Highway is $30 \mathrm{ft}$. above water, olevated on 2,600 concrete logs, oach 54 in. in diametor and ombedded $100 \mathrm{ft}$. into the sea-floor. 'The structure is designed to withstand hurricane winds, a $10-\mathrm{ft}$. rise in som-lovel, and oven $14 \cdot 5-\mathrm{ft}$. ocoan swolls. The tunnol sections account for two miles of the total span, one being $5,450 \mathrm{ft}$. long under the Chesapeake Channel, tho other 5,738 ft. under Thimble Shoal-both are main shipping channels. Each tunnel, stated to be as wide and high as a throw-storey building, was prefabricated, floatod to site, thon encased in concrete and sunk end-to-end in deep trenches excavated under the shipping lanos. The vital statistics of this bridge tunnol are that it took 1,000 men 3.5 years to construct, used 550,000 cubic yards of conerete; 55,000 tons of steel; 34,000 carloads of rosk; and more than 5 million subic yards of sand-fill. Another interesting feature of the design is the use of 14,700 elastic bearing pads the size of "standard desk dictionmries". "Laminated of nooprene synthetic rubbor around steel plates . . . the pads separate elovated 75 -foot, 65 -ton road sections from their supports. Thus they prevent concrete grinding and cracking caused by movement from thormal expansion and contraction or wind and water current". An illustratod articlo entitlod "Soagoing Roadway Rides on Rubber", by H. E. Davis, published in the Du Pont Magazine (57, No. 4, 13; JulyAugust, 1963) and from which the forogoing data aro taken, givos many other technical details of this romarkable achievemont.

\section{Antibodies}

Antibodies is the title of a recont issue of the British Medical Bulletin, which contains a sories of authoritativo articlos by recognized experis each dealing with a particular aspect of the study of these substanees $(19$, No. 3; Soptembor 1963. Symposium on Antibodies. Pp. 169$262+4$ plates. London: The British Council, 1963. 30s.). Concise papers on the nature of antigen antibody roaction, sonsitivity of methods of detecting antibodies, the isolation of antibodies, their chemieal structure, $\gamma$-globulin metabolism, factors affecting antibody response, origins of immunological competence, as well as the nature of antitoxins, reagins, and auto-antibodies are among topies included. In the introduction, Prof. A. A. Miles, the chairman of the planning committes of Antibodies, reminds us that the story of antibodies began in 1890 with the demonstration by von Behring and Kitasato of the specifie antitoxic property of the serum of animals some weeks after the injection of tetanus toxin. Almost throo-quartors of a contury has passed sinco then, and during that timo not only has detailed knowlodge of the subject inereased enormously, but also wo have a much deeper undorstanding of the process of antibody production. The editors are to be congratulatod on hiving compressed so much into the space availablo and yet left us with a lucid and fascinating picture of present-day ideas on this important aspect of immunology.

\section{Archæology in Western New South Wales}

A RECHNT issuo of the Records of the Australian Museum contains an important articlo on "The Archæology of Mootwingee, Westorn New South Wales", by F. D. MeCarthy and N. W. G. MacIntosh (Vol. 25, No. 13; Decomber 3, 1962. Pp. 249-298+ plates 19-27. Sydney: The Australian Museum, 1962). This deseribes the paintings and ongravings which ean be soon in two principal sites, called Main Gallory and Dingo Rock. The existence of this art has been known for 100 years, and was probably discovered by a momber of the Burke and Wills party in 1860 . The art consists of representations of humans, weapons and animals, and is considerod in some nases to show incidents in the lifo of the Aborigines. The Dingo Rock decorations are believed to be at least 300 years old, probably moro, on the basis of the fracturing and weathoring of the rock following its engraving. The report attempts to interpret some of the scones and objects in the light of local information; while knowledge of the technique of the engravings has been lost, certain groups can to day be explainod as portrayals of Aboriginal myths. In tho same area, a sories of painted rock shelters were recorded, and excavations made of certain of thoir floor deposits. In no case can the stone implomonts recovered be related to the series of paintings, and it seems probable that occupation of these sholters ceased well bofore the decoration was made.

\section{Paul Instrument Fund Grants}

TrF: Paul Instrument Fund Committee has made grants as follows: $£ 12,800$ to A. H. W. Beck, lecturer in engineering, University of Cambridge, for the construction of apparatus for the amplification and generation of 